\title{
Genetic diversity and differentiation of Taxodium in the south-eastern United States using cleaved amplified polymorphic sequences
}

\author{
YOSHIHIKO TSUMURA* $†$, NOBUHIRO TOMARU†, \\ YOSHIHISA SUYAMA§ \& SYDNEY BACCHUS
}

\begin{abstract}
$\dagger$ Bio-resources Technology Division, Forestry and Forest Products Research Institute, Kukizaki, Ibaraki 305-8687, Japan, $₫$ Laboratory of Forest Ecology and Physiology, School of Agricultural Sciences, Nagoya University, Nagoya 464-8601, Japan, §Sugadaira Montane Research Centre, University of Tsukuba, Sanada, Nagano 386-2201, Japan and Institute of Ecology, The University of Georgia, Athens, Georgia 30602-2202, U.S.A.
\end{abstract}

Two taxa of Taxodium, bald cypress and pond cypress, occur in the south-eastern United States. The ranges of these taxa overlap in the south-eastern Coastal Plain, with the range of the latter being more restricted. Although these taxa co-occur throughout a portion of the more expansive range of bald cypress (Taxodium distichum (L.) L. C. Rich), the habitats of the two taxa appear to differ. Consequently, considerable debate has occurred regarding the taxonomic status of pond cypress. Some authors recognize pond cypress as a distinct species (Taxodium ascendens Brongn.), whereas others recognize it as a variety/ecotype (Taxodium distichum var. imbricarium (Nutt.) Croom). In this study, the genetic diversity of these two taxa was investigated using 10 DNA markers based on sequences from cDNA clones of Cryptomeria japonica. Cryptomeria is a monospecific genus native to Japan, and is a close relative of Taxodium. These markers were codominant in Cryptomeria and were presumed to be codominant in Taxodium. DNA was extracted from leaf tissue collected from six populations of bald cypress and seven populations of pond cypress throughout Florida and Georgia. The average heterozygosities of bald cypress and pond cypress were 0.386 (SE 0.040) and 0.380 (SE $0.040)$, respectively. Most of the genetic variation $(91.9 \%)$ was found within populations, $4.9 \%$ was found between populations and 3.2\% between taxa. Results of DNA analysis using cleaved amplified polymorphic sequences (CAPS) in this study did not suggest that pond cypress was a species distinct from bald cypress. Our conclusion is that the two taxa of Taxodium should be given varietal status.

Keywords: bald cypress, CAPS, Cryptomeria, pond cypress, STS, Taxodium.

\section{Introduction}

Fossil records suggest that Taxodium was widely distributed throughout North America, Europe, and East Asia from the Cretaceous to the Pleistocene (Small, 1931; Florin, 1963). As the Pleistocene seas receded, Taxodium settled into its present distribution in the south-eastern United States and Mexico. Two taxa, bald cypress and pond cypress, occur in the south-eastern United States. The ranges of these taxa overlap in the south-eastern Coastal Plain, with the range of the latter being more restricted.

*Correspondence. E-mail: ytsumu@ffpri.affrc.go.jp
The taxonomic status of Taxodium has been debated since the early 19th century (Watson, 1985). Britton (1926), Dallimore \& Jackson (1966) and Rehder (1940) recognized three species: T. distichum (L.) L. C. Rich. (bald cypress), T. ascendens Brongn. (pond cypress) and T. mucronatum Ten. (Montezuma bald cypress). Godfrey (1988) concurred with this taxonomic treatment of pond cypress and bald cypress, suggesting temporal differences in phenology.

Watson $(1983,1985)$ evaluated morphological, anatomical, biochemical and cytological aspects of pond cypress and bald cypress, and concluded that the differences between them for the characteristics he considered were minor. He suggested that pond cypress be considered as a variety of bald cypress ( $T$. distichum 
var. imbricatum (Nutt.) Croom). He supported the hypothesis that pond cypress diverged from bald cypress, via isolated populations of bald cypress throughout the Coastal Plain during the Wisconsin Continental Glaciation. At this time, the genus was displaced southward, in conjunction with directional selection pressure exerted by habitats with reduced nutrient status and increased frequency or intensity of drought (Watson, 1983). Neufeld (1986) reported the ecophysiological implications of tree architecture for the two taxa, concluding that the morphology exhibited by pond cypress includes evolutionary adaptations resulting from climatically induced habitat changes. Miller et al. (1993) also found differences in interstitial soil $\mathrm{pH}$ between pond cypress $(\approx 4.5)$ and bald cypress $(\approx 6-7)$ populations. In the same study, Miller et al. repeated bioflavonoid analysis of leafy branchlet tissue from one of the populations Watson (1983) had evaluated, and concluded that these chemical 'fingerprints' can be altered by the condition, or health of the tree. Therefore, biflavonoids appear to have limited use as evidence of taxonomic status.

In molecular phylogenetic studies, no differences were apparent between the two taxa using PCR-RFLP analysis of six genes of chloroplast DNA (Tsumura et al., 1995). Lickey (1996) also failed to find significant differences between the two taxa after allozyme analysis of young shoot tissue from trees across their geographical range.

Sequence-Tagged Site (STS) primers have been used to generate PCR-based markers in many plant species, including Populus (Bradshaw et al., 1994), Cuphea (Slabaugh et al., 1997), Pinus taeda (Harry et al., 1998) and Picea mariana (Perry \& Bousquet, 1998). STS-based cleaved amplified polymorphic sequences (CAPS) (Konieczny \& Ausubel, 1993; Drenkard et al., 1997), are more reliable and convenient for genomic mapping and population genetics. The cDNA clones represent expressed genes and are extremely useful for establishing anchor points in genomic mapping and other genetic studies. Recently, we have developed STS markers in Cryptomeria japonica, a species closely related to Taxodium (Brunsfeld et al., 1994; Tsumura et al., 1995). The STS markers were derived from cDNA sequences of $C$. japonica (Tsumura et al., 1997) and half have been mapped in linkage groups (Mukai et al., 1995). The sequences of PCR primers for STSs therefore are especially well conserved in closely related genera, such as Taxodium and Cryptomeria (Brunsfeld et al., 1994; Tsumura et al., 1995). Tsumura et al. (1997) reported that about half of the STS markers from C. japonica could be amplified by PCR in Taxodium as single fragments.

We have applied the CAPS markers of $C$. japonica to Taxodium populations to investigate the genetic variation within and between populations, and between the two taxa in question. Using these results, we have evaluated the efficiency of CAPS markers, and the genetic relationship and taxonomic status of the two cypresses using these conserved markers.

\section{Materials and methods}

\section{Plant materials}

In early September 1994, fresh leafy branchlets were collected from 122 trees representing seven populations of pond cypress, and 130 trees representing six populations of bald cypress, in Georgia and Florida (Fig. 1). Samples were collected from an average of 19.55 trees in each population, with considerable distance between sampled trees to minimize sampling half-sib individuals. Ages of sampled trees were not determined but sizes of sampled trees tended to be similar within each population. All collection locations contained populations of pond cypress and bald cypress in sufficiently close proximity for potential cross-pollination except possibly Highlands Hammock, Tates Hell and Tocoi. Collected plant tissue was stored at $-30^{\circ} \mathrm{C}$ prior to DNA extraction.

\section{Laboratory analysis}

Total DNA was extracted from each sample using the modified CTAB method of Murray \& Thompson (1980). CAPS markers based on sequences of cDNA clones of C. japonica (Tsumura et al., 1997) were used to evaluate the genetic diversity and differentiation of pond cypress and bald cypress. Eighty STS markers of C. japonica were evaluated for use in this study. Basic PCR amplification conditions were as follows: reaction mixtures $(100 \mu \mathrm{L})$ contained $10 \mathrm{~mm}$ Tris- $\mathrm{HCl}, \mathrm{pH} 8.3,50$ $\mathrm{mm} \mathrm{KCl}, 1.5 \mathrm{~mm} \mathrm{MgCl}_{2}, 0.1 \mathrm{~mm}$ dNTP, 100 pmol of each primer, $50 \mathrm{ng}$ of template DNA, and 2.5 units of Taq polymerase. PCR amplification was carried out for $5 \mathrm{~min}$ at $94^{\circ} \mathrm{C}$, followed by $36-45$ cycles of $40 \mathrm{~s}$ at $94^{\circ} \mathrm{C}$, $40 \mathrm{~s}$ at 58 or $60^{\circ} \mathrm{C}$, and $80 \mathrm{~s}$ at $72^{\circ} \mathrm{C}$, with a final 5-min incubation at $72^{\circ} \mathrm{C}$ using a PC700 model from Astech Co. Ltd, or an MJ Research Programmable Thermal Controller PTC100. In the survey for polymorphic STS markers in Taxodium, we used four individuals of each Taxodium variety.

Each PCR product was digested with eight fourbase-cutter restriction enzymes (AluI, HaeIII, HhaI, MspI, NdeII HinfI, TaqI and RsaI) and electrophoresed in either $2 \%$ agarose gels or $7.5 \%$ polyacrylamide gels. Ten suitable polymorphic STS markers were identified out of the total of 80 primer gels tested in Taxodium (Table 1). 
Fig. 1 Natural distribution of Taxodium in the U.S.A. (Wilhite \& Toliver, 1990) and sampling sites. $\mathrm{P}$ and $\mathrm{B}$ indicate pond cypress and bald cypress populations, respectively. The dashed line indicates the range of pond cypress. The following abbreviations were used for each population: Fargo, FAR; Tocoi, TCI; pond cypress populations in Tosohatchee, TP1 and TP2; bald cypress in Tosohatchee, TB1 and TB2; Loxahatchee, LXH; pond cypress populations in Starkey, SD1 and SD2; Tates Hell, THL; pond cypress in St. Mark, SMP, bald cypress in St. Mark, SMB; and Highland Hammock, HHM.

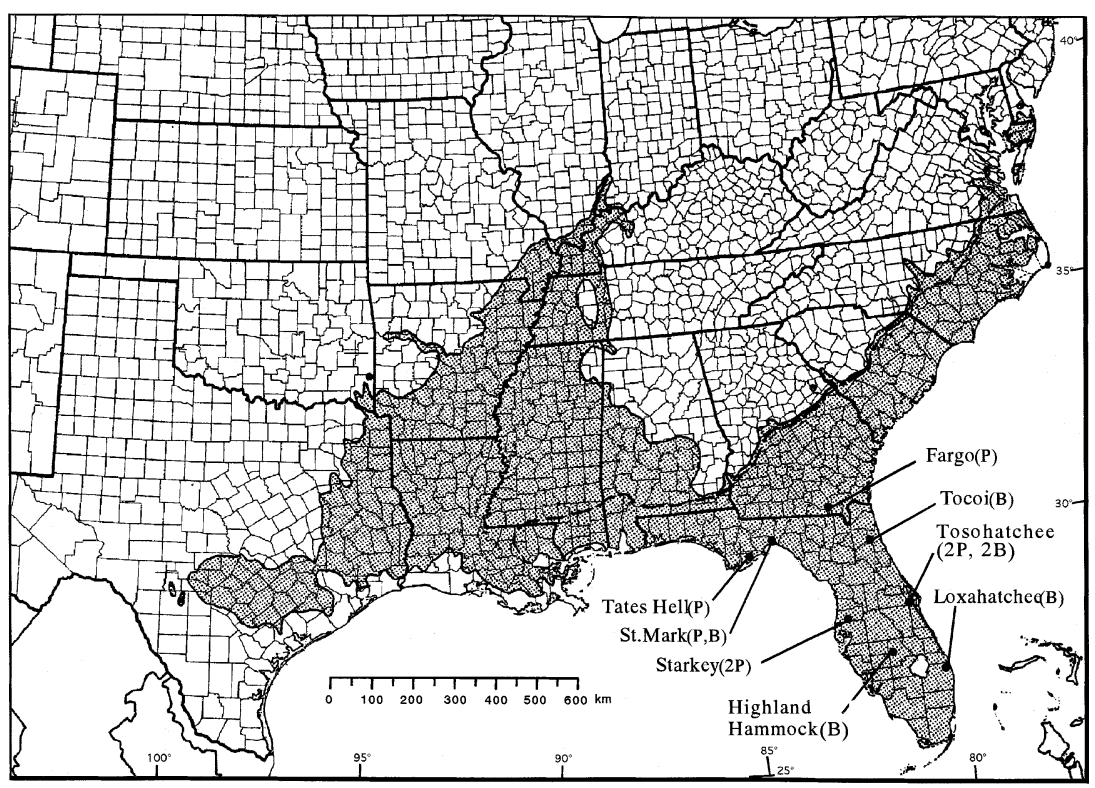

\section{Statistical analysis}

To estimate within-population variation, we used the following measures calculated from the allele frequencies of all loci analysed: the proportion of polymorphic loci $(P l)$ at the $95 \%$ criterion; the average number of alleles per locus $\left(N_{\mathrm{a}}\right)$, and the averages of expected heterozygosities $\left(H_{\mathrm{e}}\right)$, where unbiased values for $H_{\mathrm{e}}$ were also estimated (Nei, 1978).

The fixation indices, $F_{\mathrm{IS}}\left(=1-H_{\mathrm{o}} / H_{\mathrm{e}}\right), F_{\mathrm{IT}}$ and $F_{\mathrm{ST}}$, for polymorphic loci and over all loci, were determined (Nei \& Chesser, 1983) for comparison of the observed genotype frequencies to the expectations of HardyWeinberg equilibrium. Deviations from such expectations were analysed using the chi-squared test (Workman \& Niswander, 1970).

Between-population variation was estimated in terms of the following statistics. Nei's gene diversity statistics (Nei, 1973) were estimated as follows: $H_{\mathrm{T}}=H_{\mathrm{P}}+D_{\mathrm{PV}}+$ $D_{\mathrm{VT}}, H_{\mathrm{V}}=H_{\mathrm{P}}+D_{\mathrm{PV}}$ and $G_{\mathrm{PV}(\mathrm{T})}=D_{\mathrm{PV}} / H_{\mathrm{T}}, G_{\mathrm{VT}}=$ $D_{\mathrm{VT}} / H_{\mathrm{T}}$, where $H_{\mathrm{T}}$ is the total population gene diversity, $H_{\mathrm{P}}$ and $H_{\mathrm{V}}$ are the average gene diversities within populations and variety, respectively, and $D_{\mathrm{VT}}$ and $D_{\mathrm{PV}}$ are the average gene diversity between variety and between populations within variety, respectively, and $G_{\mathrm{PV}(\mathrm{T})}$ and $G_{\mathrm{VT}}$ are the relative extent of gene differentiation among populations within variety and between taxa, respectively. These analyses were carried out using the GENESTRUT program (Constantine et al., 1994). To estimate the amount of gene flow between populations, the number of migrants exchanged per generation, $\mathrm{Nm}$, also was calculated indirectly from values of $G_{\mathrm{PV}(\mathrm{T})}$ (or $G_{\mathrm{VT}}$ ) at each locus and the values over all loci by application of Wright's infinite island formula (Wright, 1931): $N m=\left(1-G_{\mathrm{PV}(\mathrm{T})}\right.$ or $\left(G_{\mathrm{VT}}\right) / 4 G_{\mathrm{PV}(\mathrm{T})}$ or $G_{\mathrm{VT}}$, where $N$ is the effective population size and $m$ is the proportion of migrants exchanged per generation. Finally, Nei's unbiased genetic distances were calculated for all population pairs (Nei, 1972, 1978). The dendrogram was constructed based on the genetic distance matrix using UPGMA (Sokal \& Michener, 1958) and neighbourjoining (NJ) methods (Saito \& Nei, 1987). Bootstrap analysis was carried out using the DISPAN computer program (Ota, 1993).

\section{Results}

\section{STS-based codominant CAPS markers}

In Taxodium, single PCR products were obtained for 40 of the Cryptomeria STSs. These were cleaved with eight different restriction endonucleases. Ten of these 40 markers showed polymorphic restriction patterns, and all patterns appeared to be codominant (Fig. 2). Therefore, these 10 markers were used to evaluate the genetic diversity of Taxodium (Table 1).

\section{Genetic diversity of Taxodium}

Genetic diversity of Taxodium was investigated using only polymorphic CAPS markers. Therefore, the average unbiased heterozygosities were relatively high, ranging from 0.325 to 0.432 (Table 3). The average heterozygosities of pond cypress and bald cypress were 0.380 and 0.395 , respectively. The average number of alleles per locus was 2.00 for most populations. The 
Table 1 PCR-based codominant markers developed from cDNA clones of Cryptomeria japonica used to assess genetic diversity in Taxodium

\begin{tabular}{|c|c|c|c|c|c|c|}
\hline Locus & Primer & PCR condition $\dagger$ & $\begin{array}{l}\text { Fragment } \\
\text { size (bp) }\end{array}$ & Enzymet & $\begin{array}{l}\text { Fragment size in } \\
\text { C. japonica (bp) }\end{array}$ & Homology§ \\
\hline CD618 & $\begin{array}{l}\text { 5'-CAA GGA CAA CGG GCA AAA AT-3' } \\
\text { 5'-GAA CTG GGT TCC AAG GCT AT-3' }\end{array}$ & 60,40 cycles & 1000 & $\operatorname{Taq} \mathrm{I}$ & 1000 & \\
\hline$C D 41$ & $\begin{array}{l}\text { 5'-GAA TCC AAA ACC ACT TGC TA-3' } \\
\text { 5'-ACA TTC ACG ACC CTC CGT AT-3' }\end{array}$ & 58,45 cycles & 2000 & $\operatorname{Hinf} \mathrm{I}$ & 2000 & $\begin{array}{l}\text { Arabidopsis thaliana } \\
\text { cDNA clone } 113 \mathrm{~J} 6 \mathrm{~T} 7\end{array}$ \\
\hline CD1514 & 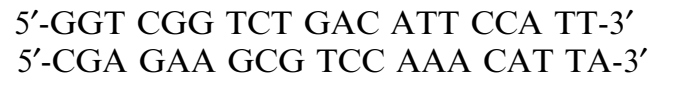 & 60,40 cycles & 500 & NdeII & 500 & $\begin{array}{l}\text { Pinus sylvestris } C H S \text { gene } \\
\quad \text { for chalcone synthase }\end{array}$ \\
\hline CD620 & $\begin{array}{l}5^{\prime} \text {-AGG CCA AAC CCT CAG AAG TA-3' } \\
5^{\prime} \text {-GCT GGG AAG TCC TCT AAG AA-3' }\end{array}$ & 56,40 cycles & 550 & RsaI & 550 & $\begin{array}{l}\text { Arabidopsis thaliana cDNA } \\
\text { clone } 118 \text { A8T7 }\end{array}$ \\
\hline CD1852 & 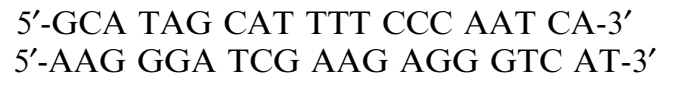 & 58,36 cycles & 350 & RsaI & 350 & \\
\hline CD1894 & 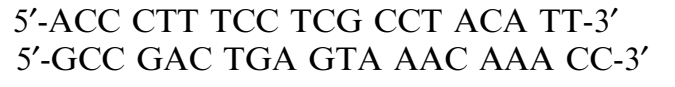 & 60,40 cycles & 750 & HhaI & 750 & $\begin{array}{l}\text { Oat TUB1 mRNA for } \\
\text { beta-tubulin (partial) }\end{array}$ \\
\hline CD1237 & $\begin{array}{l}5^{\prime} \text {-GGA ATC GGA TGG GTT ATC TG-3' } \\
5^{\prime} \text {-AGA ATC CGG GAC CAA ATC TA-3' }\end{array}$ & 60,40 cycles & 900 & HhaI & 900 & $\begin{array}{l}\text { Arabidopsis thaliana cDNA } \\
\text { clone } 120 \mathrm{C} 7 \mathrm{~T} 7\end{array}$ \\
\hline CD1613 & $\begin{array}{l}\text { 5'-GGT GAA CAA GAA AGG GAA AT-3' } \\
5^{\prime} \text {-ATG TGT TGT CTG GCT TGG TA-3' }\end{array}$ & 60,40 cycles & 800 & HaeIII & 800 & \\
\hline CD1179 & $\begin{array}{l}5^{\prime}-\mathrm{TGG} \text { GTT TGG GCA TAA GTC TG-3' } \\
5^{\prime} \text {-TTG CCC CTG TTG TTT TAT CC- } 3^{\prime}\end{array}$ & 58,40 cycles & 800 & HaeIII & 800 & \\
\hline$C D 402$ & $\begin{array}{l}\text { 5'-CCT GCC CAT GGT GAA AGT AA-3' } \\
\text { 5'-TTG AAT CCA GAG GCT TGA AA-3' }\end{array}$ & 58,40 cycles & 350 & Alu $\mathrm{I}$ & 350 & \\
\hline
\end{tabular}

$\uparrow$ †nnealing temperature and PCR cycles. $¥$ Polymorphic enzyme. §Significant with BLAST homology test. 
(a)

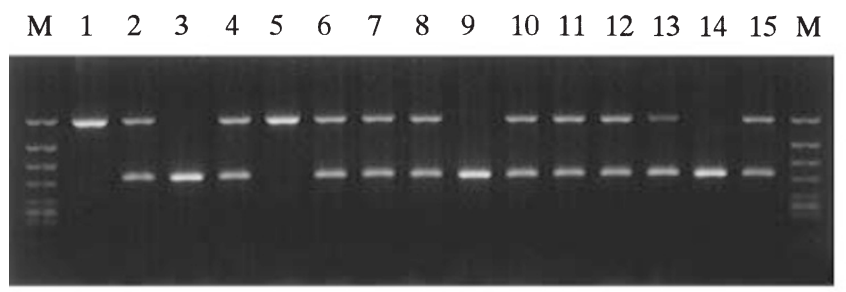

(c)

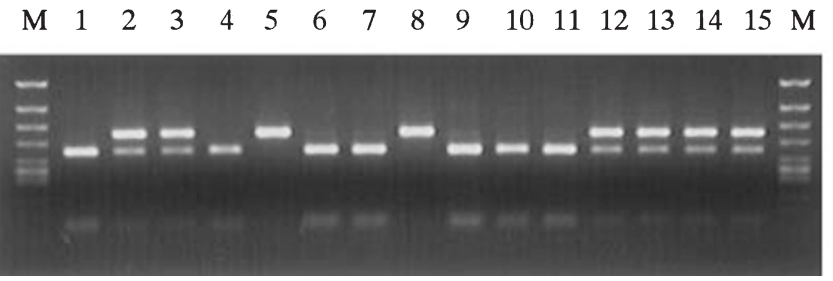

(b)

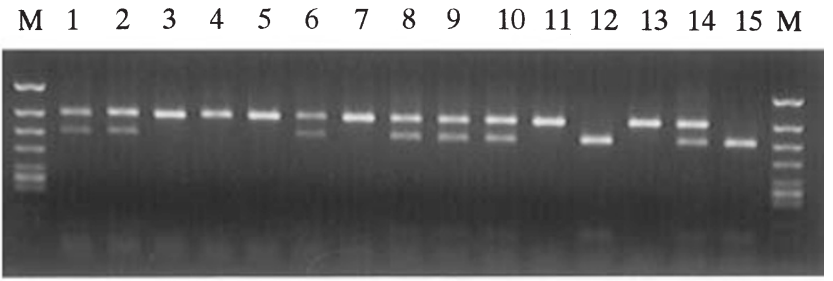

(d)

$\begin{array}{lllllllllllllllll}\mathrm{M} & 1 & 2 & 3 & 4 & 5 & 6 & 7 & 8 & 9 & 10 & 11 & 12 & 13 & 14 & 15 & \mathrm{M}\end{array}$

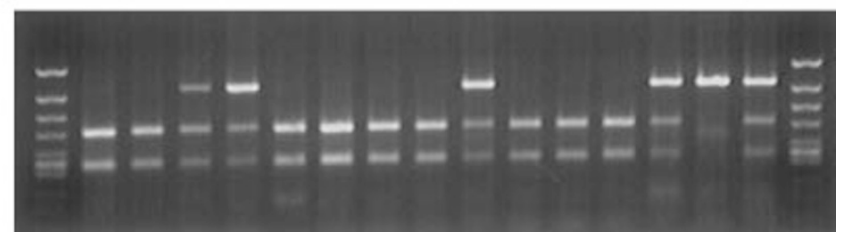

Fig. 2 Restriction patterns of CAPS markers in Taxodium. (a) CD618/TaqI; (b) CD1894/HhaI; (c) CD620/RsaI; (d) CD1613/ HaeIII. Both marginal lanes in each panel show DNA size markers of X174/HincII, and the other lanes indicate the investigated individuals.

CD1237 and CD1179 loci in the Tosohatchee P2 (TP2) population were monomorphic, as was the CD1179 locus of the Loxahatchee (LXH) population. Consequently, the average heterozygosities of these two loci were lower than those of the other eight (Table 2). A clear difference for the average allele frequencies of CD618 between the two cypress taxa was noted. The average frequencies of the $a$ allele at the CD618 locus in pond cypress and bald cypress were 0.875 and 0.390 , respectively (Fig. 3). The $b$ allele frequency of $C D 1179$ in the Fargo population (0.940) was greater than for the remaining populations $(0.000-0.196)$.

The gene diversity within populations $\left(H_{\mathrm{P}}\right)$ varied for each locus, ranging from 0.129 for $C D 1237$ to 0.500 for $C D 1514$. The gene diversity in the total populations $\left(H_{\mathrm{T}}\right)$ also ranged from 0.130 to 0.500 (Table 5). Half of the fixation indices $\left(F_{\text {IS }}\right)$ showed statistically significant values, at the $5 \%$ probability level for $C D 618$ and $C D 1179$ and at the $1 \%$ level for CD1514, CD620 and $C D 402$ (Table 4). The chi-squared value of $C D 1514$ had particularly high significance. The $F_{\mathrm{ST}}$ values showed statistical significance at seven loci, and the value of $F_{\mathrm{ST}}$ over all loci also was statistically significant.

Genetic variation within populations, between populations within taxa, and between taxa was $0.919,0.049$ and 0.032 , respectively (Table 5). The numbers of migrants exchanged per generation among populations within and between taxa $(\mathrm{Nm})$ were 4.85 and 7.56, respectively. The unbiased genetic distances between populations ranged from 0.000 to 0.166 and their average was 0.042 . There was no clear geographical tendency in the allele frequencies or heterozygosities among populations. The dendrogram using the UPGMA method showed little differentiation between the two taxa of Taxodium (Fig. 4), and the NJ tree showed a very similar dendrogram to the UPGMA tree.

\section{Discussion}

We have applied CAPS markers from cDNA sequences of $C$. japonica to investigate the genetic diversity of natural populations of $C$. japonica and concluded that there is no large difference in results between allozyme and CAPS studies (Tsumura \& Tomaru, 1999). Because Taxodium and Cryptomeria are closely related genera, we believe that the CAPS markers we have used are as appropriate for investigating the genetic diversity of Taxodium as allozyme studies.

The polymorphic DNA markers, derived from STS sequences of cDNA from $C$. japonica, have been used for other coniferous species (Tsumura et al., 1997). When screening for suitable markers in Taxodium, dominant markers and those considered to encode multicopy genes were excluded. The STS markers were presumed to correspond to expressed genes because they were derived from sequences of cDNA clones of C. japonica. These regions were presumed to correspond to genes in Taxodium because cDNA sequences between the closely related taxa (e.g. Taxodium and Cryptomeria) generally are conserved (Brunsfeld et al., 1994; Tsumura et al., 1995). The inheritance of these markers was not investigated in Taxodium because plant material from 
Table 2 Allele frequency at 10 loci in 13 populations of Taxodium

\begin{tabular}{|c|c|c|c|c|c|c|c|c|c|c|c|c|c|c|c|c|}
\hline Locus & Allele & \multicolumn{8}{|c|}{ Pond cypress } & \multicolumn{7}{|c|}{ Bald cypress } \\
\hline CD618 & $\mathrm{b}$ & 0.380 & 0.067 & 0.067 & 0.100 & 0.060 & 0.088 & 0.111 & 0.125 & 0.620 & 0.640 & 0.740 & 0.540 & 0.389 & 0.733 & 0.610 \\
\hline$C D 41$ & $\mathrm{a}$ & 0.227 & 0.308 & 0.367 & 0.400 & 0.208 & 0.143 & 0.438 & 0.299 & 0.220 & 0.313 & 0.104 & 0.300 & 0.382 & 0.143 & 0.244 \\
\hline$C D 1514$ & $\mathrm{~b}$ & 0.480 & 0.500 & 0.567 & 0.467 & 0.480 & 0.500 & 0.500 & 0.499 & 0.500 & 0.500 & 0.500 & 0.500 & 0.500 & 0.500 & 0.500 \\
\hline \multirow[t]{2}{*}{ CD620 } & $\mathrm{a}$ & 0.300 & 0.367 & 0.500 & 0.600 & 0.640 & 0.563 & 0.556 & 0.504 & 0.600 & 0.440 & 0.360 & 0.400 & 0.333 & 0.367 & 0.417 \\
\hline & b & 0.700 & 0.633 & 0.500 & 0.400 & 0.360 & 0.437 & 0.444 & 0.496 & 0.400 & 0.560 & 0.640 & 0.600 & 0.667 & 0.633 & 0.583 \\
\hline$C D 1852$ & $\mathrm{a}$ & 0.660 & 0.633 & 0.800 & 0.700 & 0.740 & 0.533 & 0.333 & 0.628 & 0.660 & 0.680 & 0.760 & 0.720 & 0.533 & 0.500 & 0.642 \\
\hline \multirow[t]{2}{*}{$C D 1237$} & $\mathrm{a}$ & 0.120 & 0.033 & 0.133 & 0.067 & 0.040 & 0.031 & 0.000 & 0.061 & 0.120 & 0.060 & 0.060 & 0.140 & 0.071 & 0.033 & 0.081 \\
\hline & $\mathrm{b}$ & 0.880 & 0.967 & 0.867 & 0.933 & 0.960 & 0.969 & 1.000 & 0.939 & 0.880 & 0.940 & 0.940 & 0.860 & 0.929 & 0.967 & 0.919 \\
\hline \multirow[t]{2}{*}{$C D 1613$} & $\mathrm{a}$ & 0.320 & 0.067 & 0.167 & 0.033 & 0.160 & 0.214 & 0.111 & 0.153 & 0.160 & 0.260 & 0.220 & 0.260 & 0.467 & 0.100 & 0.245 \\
\hline & b & 0.680 & 0.933 & 0.833 & 0.967 & 0.840 & 0.786 & 0.889 & 0.847 & 0.840 & 0.740 & 0.780 & 0.740 & 0.533 & 0.900 & 0.756 \\
\hline \multirow[t]{2}{*}{$C D 1179$} & $\mathrm{a}$ & 0.060 & 0.967 & 0.833 & 0.933 & 0.875 & 0.962 & 1.000 & 0.804 & 0.940 & 0.680 & 1.000 & 0.960 & 0.833 & 0.933 & 0.891 \\
\hline & b & 0.940 & 0.033 & 0.167 & 0.067 & 0.125 & 0.038 & 0.000 & 0.196 & 0.060 & 0.320 & 0.000 & 0.040 & 0.167 & 0.067 & 0.109 \\
\hline \multirow[t]{2}{*}{$C D 402$} & a & 0.480 & 0.433 & 0.533 & 0.367 & 0.420 & 0.375 & 0.444 & 0.436 & 0.300 & 0.420 & 0.560 & 0.420 & 0.633 & 0.500 & 0.472 \\
\hline & b & 0.520 & 0.567 & 0.467 & 0.633 & 0.580 & 0.625 & 0.556 & 0.564 & 0.700 & 0.580 & 0.440 & 0.580 & 0.367 & 0.500 & 0.528 \\
\hline
\end{tabular}

Table 3 The average heterozygosity $\left(H_{\mathrm{e}}\right)$, the average number of alleles per locus $\left(N_{\mathrm{a}}\right)$, the proportion of polymorphic loci $(\mathrm{Pl}, 95 \%$ criterion $)$, and the unbiased heterozygosity (unbiased $H_{\mathrm{e}}$ ) in 13 populations of Taxodium

\begin{tabular}{llrlccc}
\hline Population & $n$ & $P l$ & $N_{\mathrm{a}}(\mathrm{SE})$ & $H_{\mathrm{e}}(\mathrm{SE})$ & Unbiased $H_{\mathrm{e}}(\mathrm{SE})$ \\
\hline Pond cypress & & & & & & \\
$\quad$ FAR & 25 & 100 & 2.00 & $(0.00)$ & $0.439(0.214)$ & $0.387(0.041)$ \\
SMP & 15 & 80 & 2.00 & $(0.00)$ & $0.365(0.148)$ & $0.328(0.063)$ \\
SD2 & 15 & 100 & 2.00 & $(0.00)$ & $0.440(0.215)$ & $0.377(0.044)$ \\
SD1 & 15 & 90 & 2.00 & $(0.00)$ & $0.340(0.128)$ & $0.337(0.058)$ \\
THL & 25 & 90 & 2.00 & $(0.00)$ & $0.355(0.140)$ & $0.329(0.048)$ \\
TP1 & 17 & 80 & 2.00 & $(0.00)$ & $0.352(0.171)$ & $0.325(0.057)$ \\
TP2 & 10 & 80 & 1.80 & $(0.18)$ & $0.435(0.224)$ & $0.339(0.069)$ \\
& Mean & 17.43 & 100 & $2.000(0.00)$ & $0.389(0.168)$ & $0.380(0.040)$ \\
Bald cypress & & & & & & \\
TB2 & 25 & 100 & 2.00 & $(0.00)$ & $0.452(0.238)$ & $0.378(0.043)$ \\
HHM & 25 & 100 & 2.00 & $(0.00)$ & $0.494(0.273)$ & $0.419(0.037)$ \\
LXH & 25 & 90 & 1.90 & $(0.10)$ & $0.369(0.180)$ & $0.309(0.056)$ \\
TCI & 25 & 90 & 2.00 & $(0.00)$ & $0.396(0.197)$ & $0.399(0.043)$ \\
TB1 & 15 & 100 & 2.00 & $(0.00)$ & $0.473(0.255)$ & $0.432(0.039)$ \\
SMB & 15 & 90 & 2.00 & $(0.00)$ & $0.341(0.165)$ & $0.326(0.057)$ \\
& 21.67 & 100 & $2.000(0.00)$ & $0.423(0.216)$ & $0.386(0.040)$ \\
Mean & 19.55 & 100 & $2.000(0.00)$ & $0.407(0.184)$ & $0.395(0.036)$ \\
\hline
\end{tabular}

(C) The Genetical Society of Great Britain, Heredity, 83, 229-238. 
crosses was not available. However, inheritance of these markers in $C$. japonica provided the basis for use of these genes as putative loci.

The average unbiased heterozygosities of pond cypress and bald cypress ranged from 0.325 to 0.432 , whereas the average heterozygosities were 0.380 and 0.395 , respectively. Hamrick \& Godt (1989) summarized levels of allozyme variation at the species and popula-
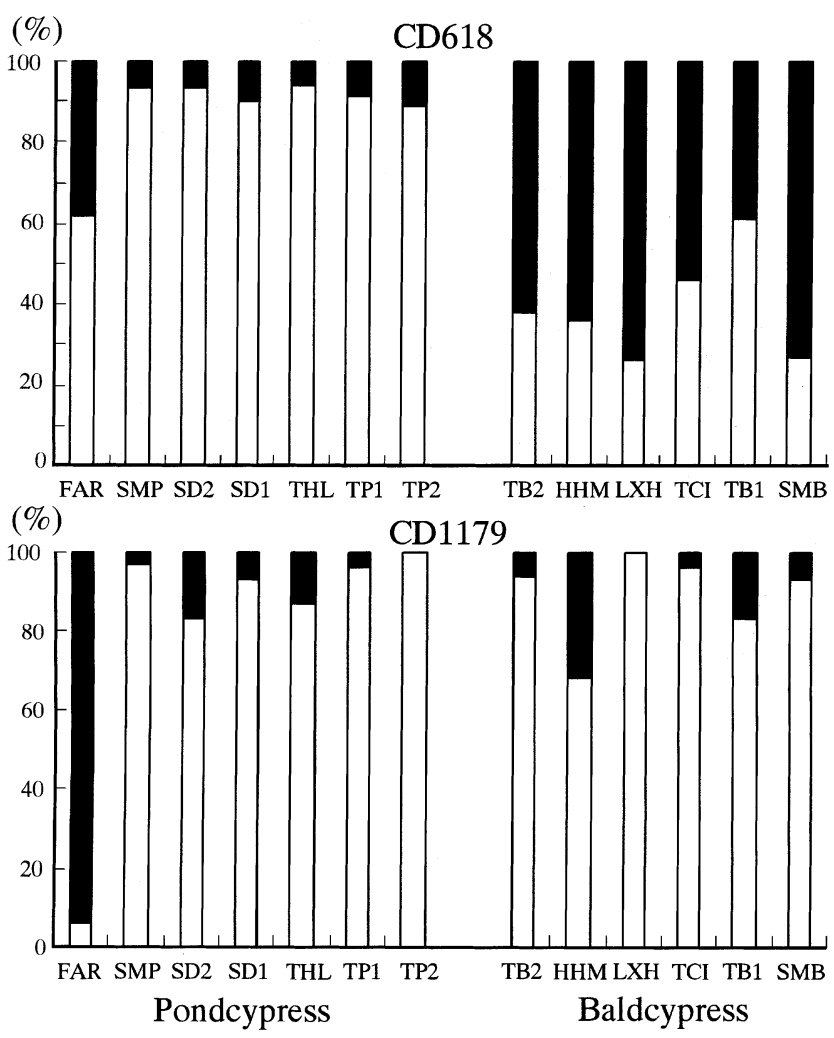

Fig. 3 Allele frequencies of 13 populations of Taxodium at the $C D 618$ and $C D 1179$ loci. Open and solid portions of bars show $a$ and $b$ alleles, respectively. tion levels for species with different attributes. This allows us to compare the data between isozyme and CAPS marker studies because Hamrick \& Godt (1989) also used only polymorphic loci when they calculated their values $\left(H_{\mathrm{T}}\right.$ and $\left.H_{\mathrm{S}}\right)$. The average heterozygosity found for CAPS loci was approximately $30 \%$ greater than that of the isozymes.

Ten putative CAPS loci were investigated for populations of two Taxodium taxa that are sympatric in the south-eastern Coastal Plain. Based on our data, only one of these loci (CD618) showed clear differences in allele frequencies between the two taxa (Table 2). All pond cypress populations except the population in Fargo, Georgia (FAR) had high frequencies of the $a$ allele. Bald cypress populations tended to have low frequencies of the same allele.

Five loci were not in Hardy-Weinberg equilibrium according to the $F_{\text {IS }}$ values. The mean values of $F_{\text {IS }}$ indices across populations varied from locus to locus, except for loci $C D 1514$ and $C D 620$. This observation corresponds with the negative mean values of $F_{\text {IS }}$ found across these loci in most populations of the two taxa. These small excesses of heterozygotes may be the result of selection but it remains unclear in these data. The genetic distance between the two taxa was only 0.043 , except for the Fargo population of pond cypress, which had a value of 0.071 (Fig. 3). However, the genetic differentiation among the remaining pond cypress populations was very small.

At the CD1179 locus, all populations surveyed had high frequencies of the $a$ allele, except the Fargo population, which was almost fixed for the $b$ allele. The pond cypress population in Fargo was the most northern population investigated in this study, and was in close proximity to the Suwannee River. Unfortunately, plant material could not be collected from a sufficient number of trees from the co-occurring bald cypress population for reliable analysis. Therefore,

Table 4 F-statistics for 10 loci in Taxodium

\begin{tabular}{|c|c|c|c|c|c|c|c|c|}
\hline Locus & $F_{\text {IS }}$ & $\chi^{2}$ & d.f. & $P$ & $F_{\mathrm{ST}}$ & $\chi^{2}$ & $P$ & $F_{\text {IT }}$ \\
\hline$C D 618$ & 0.125 & 4.00 & 12 & $<0.05$ & 0.293 & 149.50 & $<0.01$ & 0.381 \\
\hline$C D 41$ & -0.056 & 0.80 & 12 & NS & 0.030 & 15.40 & $<0.01$ & -0.024 \\
\hline$C D 1514$ & -0.935 & 223.00 & 12 & $<0.01$ & 0.000 & 0.20 & NS & -0.935 \\
\hline CD620 & -0.382 & 37.20 & 12 & $<0.01$ & 0.036 & 18.30 & $<0.01$ & -0.332 \\
\hline$C D 1852$ & 0.102 & 2.60 & 12 & NS & 0.039 & 19.70 & $<0.01$ & 0.136 \\
\hline CD1894 & 0.033 & 0.30 & 12 & NS & 0.009 & 4.40 & $<0.05$ & 0.041 \\
\hline$C D 1237$ & -0.078 & 1.60 & 12 & NS & 0.005 & 2.50 & NS & -0.073 \\
\hline$C D 1613$ & 0.046 & 0.50 & 12 & NS & 0.053 & 27.10 & $<0.01$ & 0.097 \\
\hline$C D 1179$ & 0.147 & 5.50 & 12 & $<0.05$ & 0.427 & 217.60 & $<0.01$ & 0.511 \\
\hline$C D 402$ & 0.195 & 9.60 & 12 & $<0.01$ & -0.002 & 0.80 & NS & 0.193 \\
\hline Over all loci & -0.126 & 285.20 & 120 & $<0.01$ & 0.080 & 455.60 & $<0.01$ & -0.036 \\
\hline
\end{tabular}

(C) The Genetical Society of Great Britain, Heredity, 83, 229-238. 
Table 5 Gene diversity within and between populations and varieties in Taxodium

\begin{tabular}{lcccccrc}
\hline Locus & $H_{\mathrm{P}}$ & $H_{\mathrm{T}}$ & $D_{\mathrm{PV}}$ & $D_{\mathrm{VT}}$ & $G_{\mathrm{PV}(\mathrm{T})}$ & $G_{\mathrm{VT}}$ & $H_{\mathrm{P}} / H_{\mathrm{T}}$ \\
\hline CD618 & 0.321 & 0.455 & 0.017 & 0.117 & 0.038 & 0.256 & 0.706 \\
CD41 & 0.386 & 0.398 & 0.011 & 0.001 & 0.028 & 0.002 & 0.970 \\
CD1514 & 0.500 & 0.500 & 0.000 & 0.000 & 0.000 & 0.000 & 1.000 \\
CD620 & 0.480 & 0.498 & 0.015 & 0.003 & 0.031 & 0.006 & 0.963 \\
CD1852 & 0.447 & 0.465 & 0.019 & -0.001 & 0.040 & -0.002 & 0.962 \\
CD1894 & 0.376 & 0.379 & 0.003 & 0.000 & 0.008 & 0.000 & 0.991 \\
CD1237 & 0.129 & 0.130 & 0.001 & 0.000 & 0.008 & 0.000 & 0.992 \\
CD1613 & 0.298 & 0.315 & 0.014 & 0.004 & 0.044 & 0.011 & 0.945 \\
CD1179 & 0.150 & 0.263 & 0.109 & 0.003 & 0.416 & 0.013 & 0.572 \\
CD402 & 0.497 & 0.497 & 0.000 & -0.001 & 0.001 & -0.001 & 1.001 \\
Mean & 0.358 & 0.390 & 0.019 & 0.013 & 0.049 & 0.032 & 0.919 \\
\hline
\end{tabular}

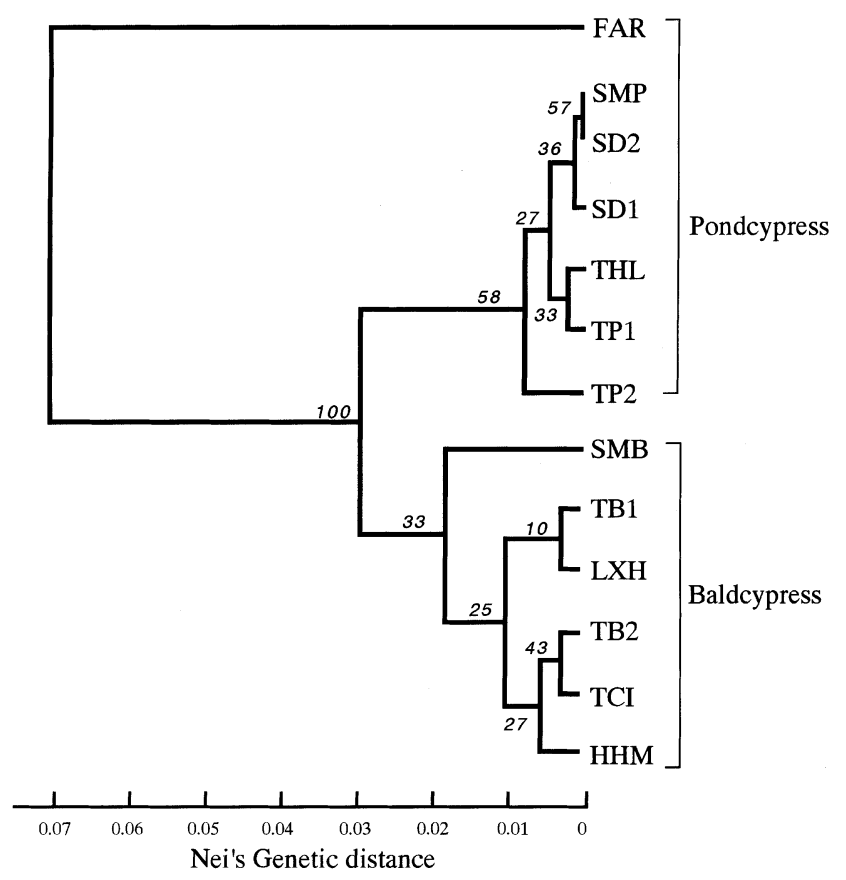

Fig. 4 Dendrogram based on genetic distance using UPGMA of 13 populations of two cypresses in Taxodium. Numbers in italics within the phylogenetic tree represent bootstrap values based on 1000 replicates.

direct comparison of these sympatric populations of bald cypress and pond cypress could not be carried out.

The genetic diversities of pond cypress and bald cypress were similar (Table 3), with the greatest genetic variation contained within populations $(91.9 \%), 4.9 \%$ between populations, and $3.2 \%$ between taxa (Table 4 ). Liu et al. (1990) reported the genetic structure of bald cypress using three isozyme loci. According to their data, the genetic variation within populations was $96.4 \%$, whereas variation between streams was only $0.4 \%$, and between populations within streams was
$1.5 \%$. However, their study was confined to a single stream system in South Carolina, and the area had been affected by thermal effluent for many years. Consequently, it is difficult to compare the genetic variation between populations in these two studies. In our study, the genetic differentiation between populations within variety $\left(G_{\mathrm{PV}(\mathrm{T})}\right)$ was $4.9 \%$ and between taxa $\left(G_{\mathrm{VT}}\right)$ it was $3.2 \%$. These values were high compared to those from the isozyme study (Liu et al., 1990). One of the reasons for this might be the large area of our study (Coastal Plain region of Florida and Georgia, $\approx 500 \mathrm{~km}$ long) compared to the single stream system in South Carolina in the allozyme study (about $15 \mathrm{~km}$ ). Liu et al. (1990) also estimated the number of migrants per generation to have an $\mathrm{Nm}$ value of 8.72 . In our study, the $\mathrm{Nm}$ values within and between taxa were 4.85 and 7.56, respectively. $\mathrm{Nm}$ values between isozyme and CAPS studies were similar. Lickey (1996) reported the genetic variation of 22 populations of two taxa in Taxodium. The heterozygosities of the two taxa were approximately the same, $H_{\mathrm{e}}=0.125$ in bald cypress and $H_{\mathrm{e}}=0.122$ in pond cypress, and the $F_{\mathrm{ST}}$ over all populations was 0.203 . The pond cypress populations made a cluster when the dendrogram based on Nei's genetic distance was constructed but the differentiation between pond cypress and bald cypress populations was very small.

The results of this study do not suggest that pond cypress is a species distinct from bald cypress. This is consistent with the findings of Watson (1983) and of Lickey (1996). Watson's research focused on morphological, anatomical, biochemical and cytological characteristics, whereas Lickey evaluated genetic structure of the two taxa using allozymes. Considering the historical background of classification of this species, we have concluded that the two taxa of Taxodium should be classified as varieties, as suggested by Watson (1983) from the analysis of several characters. 
The genetic diversity and differentiation in each species is different depending on its evolutionary history and distribution. Therefore, it is not easy to understand the level of genetic diversity and differentiation in each taxonomic level such as family, genus and species, which means there is no criterion to decide on each taxonomy level using genetic data. However, if we could add genetic data to traditional data such as morphological traits, it may be possible to decided on a suitable status in each species for which there is a taxonomic problem.

\section{Acknowledgements}

The authors thank Misako Koshiba and Chiemi Tomaru for their assistance in the laboratory, Deborah Overath for her help with arrangement of the sample collection, and Kemurio Ozaki for his help with collecting the plant material from all sites. Additional assistance in collecting plant material from various sites was provided by Culver Gidden, Ellen Hemmert and Tony Richards. Permission to collect the plant material from private and public property was provided by Robin Lewis (Tocoi Fish Camp), the Florida of Environmental Protection, and the United States Fish and Wildlife Service. The authors also thank Drs Rob Dean and Sharon Mitchell for their critical comments on the manuscript, and Dr Toru Nakamura and Emeritus Professor Kihachiro Ohba for encouragement during this study. This study was supported in part by Grant-in-Aid for International Scientific Research (no. 05041080) from the Ministry of Education, Science, Sports and Culture, and by the Programme for Promotion of Basic Research Activities for Innovative Biosciences.

\section{References}

BRADShAW, H. D., JR., VILlAR, M., WATSON, B. D., OTTO, K. G., STEWART, S. AND STETTLER, R. F. 1994. Molecular genetics of growth and development in Populus. III. A genetic linkage map of a hybrid poplar composed of RFLP, STS, and RAPD markers. Theor. Appl. Genet., 89, 167-178.

BRITTON, N. L. 1926. The swamp cypresses. J. New York Bot. Gard., 27, 205-207.

BRUNSFELD, S. J., SOLTIS, P. S., SOLTIS, D. E., GADEK, P. A., QUINN, C. J., Strenge, D. D. ET AL. 1994. Phylogenetic relationships among the genera of Taxodiaceae and Cupressaceae: Evidence from $r b c \mathrm{~L}$ sequences. Syst. Bot., 19, 253-262.

CONSTANTINE, C. C., HOBBS, R. P. AND LYMBERY, A. J. 1994. FORTRAN programs for analyzing population structure from multilocus genotypic data. J. Hered., 85, 336-337.

DAllimore, W. AND JACKSON, A. B. 1966. A Handbook of Coniferae and Ginkgoaceae, 4th edn., (revised by S. G. Harrison). Arnold Press, London.
DRENKARD, E., GLAZEBROOK, J., PREUSS, D. AND AUSUBEL, F. M. 1997. Use of cleaved amplified polymorphic sequences (CAPS) for genetic mapping and typing. In: CaetanoAnolles, G. and Gresshoff, P. M. (eds) DNA Markers. Protocols, Applications, and Overviews, pp. 187-197. WileyLiss, New York.

FLORIN, R. 1963. The distribution of conifer and taxad genera in time and space. Acta Horti. Berg., 20, 121-312.

GODFREY, R. K. 1988. Trees, Shrubs, and Woody Vines of Northern Florida and Adjacent Georgia and Alabama. The University of Georgia Press, Athens, GA.

HAMRICK, J. L. AND GODT, M. J. W. 1989. Allozyme diversity in plant species. In: Brown, A. H. D., Clegg, M. T., Kahler, A. L. and Weir, B. S. (eds) Plant Population Genetics, Breeding, and Genetic Resources, pp. 43-63. Sinauer Associates, Sunderland, MA.

HARRY, D. E., TEMESGEN, B. AND NEALE, D. B. 1998. Codominant PCR-based markers for Pinus taeda developed from mapped cDNA clones. Theor. Appl. Genet., 98, 327-336.

KONIECZNY, A. AND AUSUBEL, F. M. 1993. A procedure for mapping Arabidopsis mutations using co-dominant ecotypespecific PCR-based marker. Plant. J., 4, 403-410.

LICKEY, E. B. 1996. An Investigation of the Genetic Structure of Baldcypress and Pondcypress Using Allozyme Analysis. M.Sc. Thesis, Appalachian State University, Boone, NC.

LIU, E. H., IGLICH, E. M., SHARITZ, R. R. AND SMITH, M. H. 1990. Population genetic structure of baldcypress (Taxodium distichum) in thermally affected swamp forest. Silvae Genet., 38, 129-133.

MILleR, D., BACChUS, S. T. AND MILleR, H. 1993. Chemical differences between stressed and unstressed individuals of baldcypress (Taxodium distichum). Florida Scientist, 56, 178-184.

MUKAI, Y., SUYAMA, Y., TSUMURA, Y., KAWAHARA, T., YOSHIMARU, H., KONDO, T. ET AL. 1995. A linkage map for sugi (Cryptomeria japonica) based on RFLP, RAPD, and isozyme loci. Theor. Appl. Genet., 90, 835-840.

MURRAY, M. G. AND THOMPSON, W. F. 1980. Rapid isolation of high molecular weight plant DNA. Nucl. Acids Res., 8, 4321-4325.

NEI, M. 1972. Genetic distance between populations. Am. Nat., 106, 283-292.

NEI, M. 1973. Analysis of gene diversity in subdivided populations. Proc. Natl. Acad. Sci. U.S.A., 70, 3321-3323.

NEI, M. 1978. Estimation of average heterozygosity and genetic distance from a small number of individuals. Genetics, $\mathbf{8 9}$, 583-590.

NEI, M. AND CHESSER, R. K. 1983. Estimation of fixation indices and gene diversities. Am. Hum. Genet., 47, 253-259.

NEUFELD, H. S. 1986. Ecological implications of tree architecture for two cypress taxa, Taxodium distichum (L.) Rich. and T. ascendens Brongn. Bull. Torrey Bot. Club, 113, 118-124.

OTA, T. 1993. DISPAN. A computer program for the genetic distance and phylogenetic analysis. Institute of Molecular Evolutionary Genetics, The Pennsylvania State University, University Park, PA.

PERRY, D. J. AND BOUSQUET, J. 1998. Sequence-tagged-site (STS) markers of arbitrary genes: development, characterization 
and analysis of linkage in black spruce. Genetics, 149, 1089-1098.

REHDER, A. 1940. Manual of Cultivated Trees and Shrubs, 2nd edn. Macmillan, New York.

SAITO, N. AND NEI, N. 1987. The neighbor-joining method, a new method for reconstructing phylogenetic trees. Mol. Biol. Evol., 4, 406-425.

SLABAUGH, M. B., HUESTIS, G. M., LEONARD, J., HOLLOWAY, J. L., Rosato, C., hongtrakul, V. ET AL.. 1997. Sequenced-based genetic markers for genes and gene families: single-strand conformational polymorphism for the fatty acid synthesis gene of Cuphea. Theor. Appl. Genet., 94, 400-408.

SMALL, J. K. 1931. The cypress, southern remnant of a northern fossil type. J. New York Bot. Gard., 32, 125-135.

SOKAL, R. R. AND MICHENER, C. D. 1958. A statistical method for evaluating systematic relationships. University of Kansas Sci. Bull., 28, 1409-1438.

TSUMURA, Y. AND TOMARU, N. 1999. Genetic diversity of Cryptomeriajaponica using co-dominant DNA markers based on Sequenced-Tagged Site. Theor. Appl. Genet., 98, 396-404.

TSUMURA, Y., YOSHIMURA, K., TOMARU, N. AND OHBA, K. 1995. Molecular phylogeny of conifers using PCR-RFLP analysis of chloroplast genes. Theor. Appl. Genet., 91, $1222-1236$.

TSUMURA, Y., SUYAMA, Y., YOSHIMURA, K., SHIRATO, N. AND MUKAI, Y. 1997. Sequence-Tagged-Sites (STSs) of cDNA clones in Cryptomeria japonica and their evaluation as molecular markers in conifers. Theor. Appl. Genet., 94, 764-772.

WATSON, F. D. 1983. A Taxonomic Study of Pondcypress and Baldcypress. Ph.D. Thesis, North Carolina State University, Raleigh, NC.

WATSON, F. D. 1985. The nomenclature of pondcypress and baldcypress (Taxodiaceae). Taxon, 34, 506-509.

WILHITE, L. P. AND TOLIVER, J. R. 1990. Taxodium distichum (L.) Rich. Baldcypress. In: Burns, R. M. and Honkala, B. H. (Tech. Coords.) Silivics of North America: vol. 1. Conifers, pp. 563-572. Agriculture Handbook no. 654, U. S. Department of Agriculture, Forest Service, Washington, DC.

WORKMAN, P. L. AND NISWANDER, J. D. 1970. Population studies on southwestern Indian tribes. II. Local genetic differentiation in the Papago. Am. J. Hum. Genet., 22, 24-49.

WRIGHT, S. 1931. Evolution in Mendelian populations. Genetics, 16, 97-159. 